\title{
Chapter 21 \\ Key Research Priorities for Factories of the Future-Part II: Pilot Plants and Funding Mechanisms
}

\author{
Tullio Tolio, Giacomo Copani and Walter Terkaj
}

\begin{abstract}
Mission-oriented policies have been proposed for research and innovation in the European manufacturing industry to address grand challenges while fostering economic growth and employment. A mission is required to have clear goals that can be demonstrated also to a wide public, therefore research and innovation infrastructures play a key role to create the necessary conditions. Given the fundamental importance of public investment to promote innovation, possible funding mechanisms for industrial research and innovation are discussed. Furthermore, taking advantage of the experience gained during the Italian Flagship Project Factories of the Future, this chapter identifies three types of industrial research and innovation infrastructure that can support mission-oriented policies: lab-scale pilot plants, industrial-scale pilot plants, and lighthouse plants.
\end{abstract}

\subsection{Introduction}

The adoption of a mission-oriented approach has been proposed to reshape the European research and innovation policy agenda [1,2]. Mission-oriented policies have the potential to promote continuous innovation while providing solutions for specific problems in the scope of social grand challenges.

The previous chapter of this book [3] adopted a mission-oriented approach to propose seven missions (i.e. circular economy, rapid and sustainable industrialisation, robotic assistant, factories for personalised medicine, internet of actions, factories close to the people, and turning ideas into products) for research and innovation in

\section{T. Tolio}

Director of the Italian Flagship Project "Factories of the Future", Direttore del Progetto Bandiera "La Fabbrica del Futuro", CNR - National Research Council of Italy, Rome, Italy

T. Tolio

Dipartimento di Meccanica, Politecnico di Milano, Milan, Italy

G. Copani · W. Terkaj ( $\varangle)$

CNR-STIIMA, Istituto di Sistemi e Tecnologie Industriali Intelligenti per il Manifatturiero

Avanzato, Milan, Italy

e-mail: walter.terkaj@stiima.cnr.it 
manufacturing industry. These missions were designed taking inspiration from the scientific results of the Flagship Project Factories of the Future [4].

A mission-oriented approach requires the participation of the civil society both for the identification of the social challenges to be addressed and for the assessment of the results. This chapter deals with the problem of funding mission-related projects and demonstrating their results. Also in this case, the organisation and results of the Flagship Project Factories of the Future provided valuable input. Indeed, the flagship project designed open calls for proposals and funded small-sized research projects aimed at realizing hardware and software prototypes demonstrating the key scientific and industrial results [4]. These research projects share common traits with mission projects defined in the scope of a mission-oriented approach [1].

Section 21.2 analyses which are the current initiatives and possible funding mechanisms to implement mission-oriented policies. In particular, the need of proving the results of mission-oriented policies leads to design and develop appropriate research and innovation infrastructures that can be accessed by a large set of stakeholders. Therefore, Sect. 21.3 presents three types of industrial pilot plant that can support industrial research and innovation: lab-scale pilot plants, industrial-scale pilot plants, and lighthouse plants. Relevant examples of ongoing initiatives are presented for each type of pilot plant.

\subsection{Funding Industrial Research and Innovation}

Research and innovation play a relevant role in relation to the prosperity, health and wellbeing of the citizens in Italy and Europe. In this perspective, the public policy to support research and innovation is crucial to fund, activate, and encourage actions and players. After analysing the current research and innovation policy context (Sect. 21.2.1), this section presents a theoretical framework to address the main challenges related to research and innovation funding (Sect. 21.2.2).

\subsubsection{Current Research and Innovation Policy Context and Challenges}

Due to the fundamental role of manufacturing for guaranteeing sustainable growth and social welfare $[4,5]$, especially after the recent financial crisis, the European Commission, member states and regions have devoted considerable resources to support manufacturing research and innovation during the last decade, launching a wide number of programs and initiatives.

At European level, the Commission promoted Public-Private Partnerships (PPPs) to strategically address and manage research and innovation programs. In Manufacturing, the PPPs Factories of the Future (FoF), ${ }^{1}$ Sustainable Process Industry

\footnotetext{
${ }^{1}$ http://ec.europa.eu/research/industrial_technologies/factories-of-the-future_en.html.
} 
through Resource and Energy Efficiency (SPIRE), ${ }^{2}$ Robotics, ${ }^{3}$ and Photonics ${ }^{4}$ were established. In order to address specific innovation and uptake challenges, further initiatives were launched, such as the programs FTIPilots, ${ }^{5}$ the SME Instrument ${ }^{6}$ and the Knowledge and Innovation Communities (KICs) ${ }^{7}$ of the European Institute of Technology (EIT).

Based on the Smart Specialisation Policy, programs for inter-regional cooperation aimed also to industrial technology innovation were funded, such as the INNOSUP ${ }^{8}$ and INTERREG ${ }^{9}$ programs. The European Commission created the S3 Platform on Industrial Modernisation ${ }^{10}$ with the goal of supporting EU Regions in the definition of relevant innovation investment projects based on smart specialization and mobilizing the interest of a high number of stakeholders in Europe. Furthermore, the European Commission invested in creating a better context for technology uptake considering skill, regulation framework, and access to finance for companies, especially SMEs. Examples are Investment Plan for Europe (including the European Fund for Strategic Investments EFSI), ${ }^{11}$ the Blueprint for sectoral cooperation on skills, ${ }^{12}$ and the Long Life Learning Program. ${ }^{13}$ Furthermore, the European Investment Fund (EIF) ${ }^{14}$ manages INNOVFIN SME Guarantee Facility, COSME Equity Facility for Growth (EFG) and Loan Guarantee Facility (LGF).

At national level, all most industrialized manufacturing countries have setup research and innovation programs in manufacturing. Some examples are Platform Industrie $4.0^{15}$ in Germany, Catapult network ${ }^{16}$ and its High Value Manufacturing $\left(\right.$ HVM) division ${ }^{17}$ in UK, Usine du future ${ }^{18}$ in France, Fabbrica del Futuro ${ }^{19}$ and Piano Industria $4.0^{20}$ in Italy, Industrial Conectada $4.0^{21}$ in Spain, Made Differ-

\footnotetext{
${ }^{2}$ https://www.spire2030.eu/.

${ }^{3}$ https://ec.europa.eu/digital-single-market/en/robotics-public-private-partnership-horizon-2020.

${ }^{4}$ https://www.photonics21.org/.

${ }^{5}$ https://ec.europa.eu/programmes/horizon2020/en/h2020-section/fast-track-innovation-pilot.

${ }^{6}$ http://ec.europa.eu/programmes/horizon2020/en/h2020-section/sme-instrument.

${ }^{7}$ https://eit.europa.eu/activities/innovation-communities.

${ }^{8}$ https://ec.europa.eu/easme/en/horizon-2020-innosup.

${ }^{9}$ https://interreg.eu/.

${ }^{10} \mathrm{http} / / / \mathrm{s} 3$ platform.jrc.ec.europa.eu/industrial-modernisation.

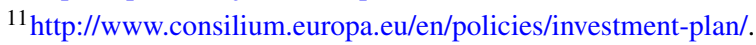

${ }^{12} \mathrm{http} / / /$ ec.europa.eu/social/main.jsp?catId=1415\&langId=en.

${ }^{13} \mathrm{http} / / /$ ec.europa.eu/education/lifelong-learning-programme_en.

${ }^{14}$ www.eif.org.

${ }^{15}$ https://www.plattform-i40.de/I40/Navigation/EN/Home/home.html.

${ }^{16}$ https://catapult.org.uk/.

${ }^{17}$ https://hvm.catapult.org.uk/.

${ }^{18} \mathrm{http}$ ://industriedufutur.fim.net/.

${ }^{19}$ http://www.fabbricadelfuturo-fdf.it/.

${ }^{20}$ http://www.sviluppoeconomico.gov.it/index.php/it/industria40.

${ }^{21} \mathrm{http}$ ///www.industriaconectada40.gob.es/Paginas/index.aspx.
} 
ent ${ }^{22}$ in Belgium, Smart Industry ${ }^{23}$ in the Netherlands. In general, these programs include actions spanning from industrial research to innovation activities. In some countries, such programs are linked to the setup of National Technology Clusters representing the priorities of the manufacturing community and coordinating manufacturing stakeholders (e.g. the Italian Cluster Intelligent Factories mentioned in Sect. 21.3.3.2).

At regional level, manufacturing policies are implemented in alignment with the concept of Smart Specialisation promoted by the European Commission. ${ }^{24}$ The majority of such programs are co-funded through the European Structural and Investment Funds (ESIF). ${ }^{25}$ Initiatives at regional level are more bounded towards innovation in specific industrial domains of excellence of local industry. Some examples are:

- innovation vouchers awarded in Baden-Württemberg ${ }^{26}$ (Germany), Lombardy ${ }^{27}$ (Italy) and Limburg ${ }^{28}$ (the Netherlands);

- specific credit and loans schemes for SMEs such as the Robotic loan of Pays de la Loire (France) and the financial tools of Finlombarda ${ }^{29}$ in Lombardy (Italy);

- the Innovation Assistant ${ }^{30}$ in Saxony-Anhalt, Brandenburg, North RhineWestphalia (Germany), Kärnten and Tyrol (Austria), through which regions cofunds employment of skilled graduates in regional SMEs to boost know-how transfer and innovation;

- measures supporting the development of new manufacturing skills, such as the Industry 4.0 training programme in Navarre ${ }^{31}$ (Spain), Compétences 2020 in Pays de la Loire (France) and the Flemish Cooperative Innovation Networks-VIS in Belgium.

With a focus on innovation infrastructure at regional level, the Vanguard Initiative (see Sect. 21.3.2.2) aims at the synergic cooperation of European Regions to boost innovation through the establishment of a European network of pilot plants based on smart specialisation. The Vanguard network of regions elaborated a specific model to fund the establishment and operation of pilot plants. Such a model implies a decreasing public contribution from the phase of pilot plants implementation, to the phase of

\footnotetext{
${ }^{22} \mathrm{http}: / / \mathrm{www} \cdot$ madedifferent.be/.

${ }^{23} \mathrm{https} / / /$ ec.europa.eu/futurium/en/system/files/ged/nl_country_analysis.pdf.

${ }^{24} \mathrm{https}: / /$ ec.europa.eu/jrc/en/research-topic/smart-specialisation.

${ }^{25} \mathrm{https} / / /$ ec.europa.eu/eip/ageing/funding/ESIF_en.

${ }^{26} \mathrm{https} / / / \mathrm{www}$.wirtschaft-digital-bw.de/en/measures/hightech-digital-innovation-voucher/.

${ }^{27} \mathrm{http}: / / \mathrm{www} . o p e n i n n o v a t i o n . r e g i o n e . l o m b a r d i a . i t / i t / s t o r i e-d i-i n n o v a z i o n e / n e w s / a l-v i a-i-v o u c h e r-$ per-la-digitalizzazione.

${ }^{28} \mathrm{https} / / /$ www.cpb.nl/sites/default/files/publicaties/download/do-innovation-vouchers-help-smescross-bridge-towards-science.pdf.

${ }^{29} \mathrm{http} / / / \mathrm{www}$. finlombarda.it/home.

${ }^{30} \mathrm{https}: / /$ ec.europa.eu/growth/tools-databases/regional-innovation-monitor/support-measure/ innovation-assistants- 0 .

${ }^{31} \mathrm{http} / / /$ clusterautomocionnavarra.com/industria-4-0/herramienta-de-auto-formacion-enindustria-4-0/.
} 
operations (service offering) up to the industrial uptake, with the necessary condition that companies complement public intervention through private co-funding.

With the goal of including in virtuous innovation processes not only the most advanced regions but also emerging manufacturing regions, recently new regions from Eastern Europe joined the Vanguard Association and specific initiatives were supported by the European Commission (e.g. the Greenomed INTERREG Mediterranean Project ${ }^{32}$ ).

Similarly to the national level and stimulated by the European Cluster Excellence Programme, ${ }^{33}$ regional Clusters play a central role in coordinating the industrial ecosystems for the definition and exploitation of regional research and innovation policies. As an example, Lombardy Region created Regional Technology Clusters as actors supporting the regional government in the definition and management of research and innovation policies in alignment with National Clusters. Among them, Associazione Fabbrica Intelligente Lombardia (AFIL) is the cluster representing the manufacturing sector. ${ }^{34}$

However, the current manufacturing policy framework presents still challenges for companies and other research and innovation manufacturing stakeholders, which are summarized as follows:

- Even if the coordination among various policies improved in the last few years, the wide number of fragmented initiatives at all geographic levels makes it difficult for companies to address in a synergic and efficient way the different funding opportunities.

- The current research funding approach is mainly technology-based, while a mission-oriented approach would be more effective to address industrial challenges [1-3].

- Existing inter-regional cooperation programs support joint activities based on a geographical proximity base, while common interests might emerge in a wider European supply chain view.

- Apart from digital technologies, funding for innovation and uptake of specific technologies is limited.

- The availability and access to innovation infrastructure to uptake research results is still limited in Europe.

- The access to research and innovation opportunities and services is unbalanced among the most industrialised and less advanced manufacturing regions.

- The role of intermediators for research and innovation, such as Clusters, is very heterogeneous in various regions and countries.

These challenges are acknowledged by European, national and regional institutions that are working cooperatively to improve the current policy context in the scope of the existing governance framework. The next European Research and Innovation programme (2021-2027) is expected to invest about 100 billion euro. Most

\footnotetext{
${ }^{32} \mathrm{https}: / /$ greenomed.interreg-med.eu/.

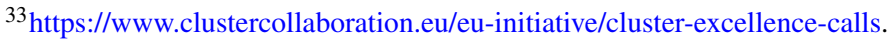

${ }^{34} \mathrm{http} / / /$ www.afil.it/.
} 
of the budget will be dedicated to the programme Horizon Europe $e^{35}$ that, building on the previous Horizon 2020, will be based on three pillars: Open Science, Global Challenges and Industrial Competitiveness, and Open Innovation.

The main novelties of Horizon Europe include:

- The key role of the European Innovation Council (EIC) ${ }^{36}$ to support breakthrough innovation.

- Research \& Innovation Missions [1] within the Global Challenges and Industrial Competitiveness pillar.

- Strengthening international cooperation.

- Enhancement of open access dissemination and exploitation.

- Simplified approaches to partnership and funding.

\subsubsection{A Framework for Research and Innovation Funding}

Research in general, and specifically industrial research, is traditionally organized through a set of sequential steps starting from basic research towards the exploitation of the results in a real industrial environment. The various phases in this chain have different aims and methodologies and, consequently, involve different actors. Basic or fundamental research is aimed at improving the scientific understanding of phenomena in general; it is manly curiosity-driven and is carried out by public bodies like universities and research bodies. On the contrary, the industrial development phase has the main objective of bringing the results of the research (e.g. a prototype or a demonstrated approach) to its industrial maturity. Consequently, the involved actors are those interested in the exploitation of the results.

Funding research has to take this structure into consideration. Basic research always requires a public funding support since it is not explicitly aimed at devising exploitable results within a defined time horizon. When moving to applied research, funding is traditionally public-private, while industrial development is in charge of venture/risk capitals or industrial partners aiming at the exploitation of the research results, although some public support is possible, e.g. in terms of tax credits.

This traditional approach to research funding has a clear and widely-accepted motivation and a fruitful implementation tradition in many countries. Nevertheless, some criticalities arose, in particular because of the increasing requests to rapidly bring the results of the research to the maturity phase and leverage on the consequent high level of innovation and competitiveness of the industry. As stated by Stokes [6], "The belief that the goals of understanding and use are inherently in conflict, and that the categories of basic and applied research are necessarily separate, is itself in tension with the actual experience of science and industry". Indeed, the link between research

\footnotetext{
${ }^{35} \mathrm{http} / / /$ ec.europa.eu/horizon-europe.

${ }^{36} \mathrm{https} / / /$ ec.europa.eu/programmes/horizon2020/en/h2020-section/european-innovation-councileic-pilot.
} 
and innovation should be strengthened to fast identify research results that have highest potential impact in industry and to set the conditions for successful exploitation. Nevertheless, establishing connections between the results of basic research and its application is a complex process entailing the need of creating the conditions for cross fertilisation, whose success is also sometimes due to serendipitous events. The link between basic and applied research should be strengthened through:

1. The central role of research and innovation infrastructures that enable basic and applied researchers to work together on goal-based research and innovation activities.

2. The possibility to fund joint basic-applied research projects. Funding could proceed through a stage-gate approach in which subsequent research and innovation stages are funded based on positive results of previous phases (gates). Funded actors may change in each phase according to the TRL level, required competences and interests.

3. Partnerships between applied and basic research bodies aiming at promoting cross fertilization paths.

4. The role of Clusters and intermediators that mobilise the different research and innovation stakeholders and provide an efficient and coordinated cooperation environment.

In particular, the next section (Sect. 21.3) will delve into the first item of the list, i.e. research and innovation infrastructures.

\subsection{Infrastructures for Industrial Research and Innovation}

The concept of mission-oriented policy is strictly related to the need of clearly demonstrating how specific innovation goals have been reached, while supporting the uptake of innovation to generate wide industrial and societal impact. Bringing research results to industrial applications is a critical issue for Europe. This is particularly true for the Key Enabling Technologies (KETs) identified by the European Commission, which have the potential to enable disruptive innovation in manufacturing [7]. Innovation infrastructures can play a fundamental role to overcome the Valley of Death, i.e. the phase ranging from Technology Readiness Level (TRL) 6-7 to 9 (commercialisation) $[8,9]$.

Companies naturally tend to stay anchored to technologies and processes that proved to perform well in the past (the path-dependent and lock-in effect reported by [10]). The adoption of technologies and solutions implying a change of manufacturing paradigm presents a set of significant concurrent risks (technical, market, organisational, and institutional risks) that companies are not often able to address $[11,12]$. Innovation infrastructures can constitute a unique protected environment where novel technologies coming from research can be cooperatively further developed and the contextual factors needed for successful technology exploitation can be 
set-up (such as market existence and acceptance, sustainable network cooperation, institutional and regulatory framework, etc.) [13]. Innovation infrastructures are also useful to set-up and monitor innovation policies, since they can be stimulated by institutional actors to implement industrial policies, or they can be used by the latter to gather trends and assess the performance of various innovations in order to manage policies contents in the long-term [14].

Despite the relevance of innovation infrastructures and the significant investments devoted to them by governments at European, National and Regional level, innovation infrastructures received limited attention from researchers [15], even though multiple definitions and taxonomies were proposed in literature. As an example, Ballon et al. [14] refer to innovation infrastructures as Test and Experimentation Platforms (TEPs) and identified five types of them: innovation platforms, living labs, open and closed testbeds, software platforms. Hellsmark et al. [16] call them Pilot and Demonstration Plants (PDPs) and classified the following types: high profile pilot and demonstration plants, (lab-scale or industrial-scale) verification pilot and demonstration plants, deployment pilot and demonstration plants, and permanent test centres.

The types of innovation infrastructure can be classified according to several dimensions, such as the maturity of the technologies of the infrastructure (TRL), the focus on technology scale-up versus (market) testing, the degree of openness of the infrastructure, the type of risks they contribute to mitigate and their goal in terms of addressing non-technical challenges (such as the generation of diffused and tacit knowledge on new technologies, the networking dimension and the needed institutional/regulatory framework) $[14,16]$.

In this chapter, three relevant types of innovation infrastructure are presented: Lab-scale Pilot Plant (Sect. 21.3.1), Industry-scale Pilot Plant (Sect. 21.3.2) and Lighthouse Plant (Sect. 21.3.3). Each type of innovation infrastructure is exemplified with specific reference to the Italian research, industrial and policy context to show the role of innovation infrastructures in a dynamic lifecycle perspective according to the maturity of the technology and of the industrial uptake process, as suggested in [16].

Lab-scale innovation infrastructures are aimed at increasing the TRL of available research results by integrating multiple technologies for the achievement of an industrial objective (Lab-scale Pilot Plants). With this goal, a selected community of key-stakeholders that contribute to generate more mature technologies in a cooperative environment should be established. Subsequently, innovation infrastructures for the wide industrial deployment of mature technologies should be built (Industry-scale Pilot Plants) to provide innovative solutions solving specific problems of manufacturing companies. Finally, permanent infrastructures are needed to guarantee continuous support for technology uptake and complete the adoption process (Lighthouse Plants).

Pilot plants will help the overall innovation system to make cross-fertilization actions in a multi-facetted, highly networked, and dynamic environment where industrial companies, universities, research institutes, policy makers, and civil society can collaborate [17]. Digital technologies dramatically increase the opportunities of vertical and horizontal integration in complex and dynamic eco-systems. The impact 


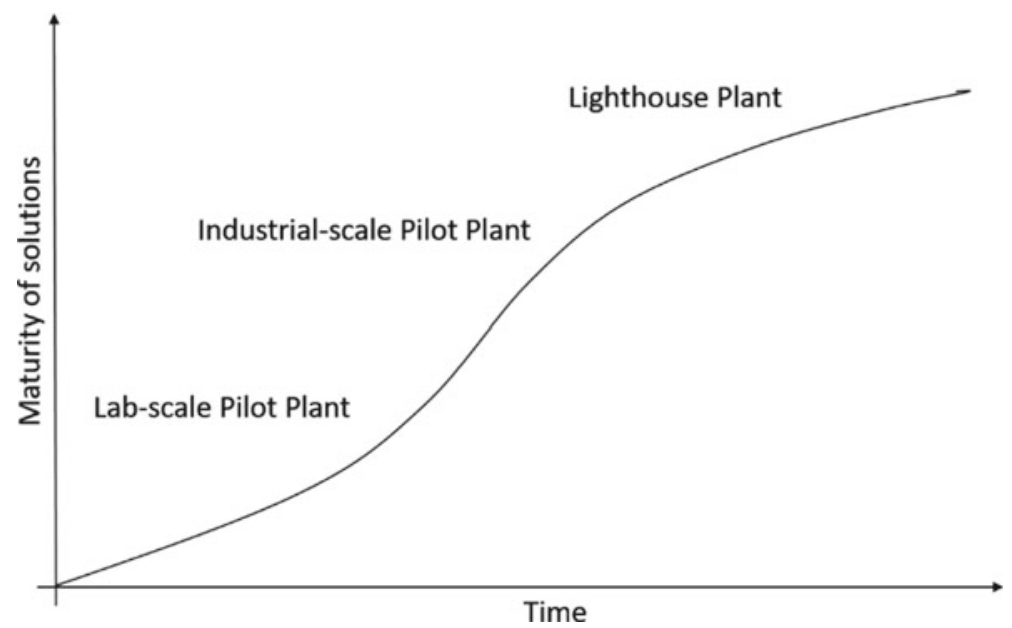

Fig. 21.1 Different type of innovation infrastructure against solutions' maturity and time (adapted from [16])

and strategic importance of pilot plants will be measured in terms of value added, better cohesion, open innovation, and social acceptance of industrial initiatives.

Referring to the framework proposed in [16], Fig. 21.1 shows three different types of infrastructure considering the maturity of solutions (including technologies, organization, business model, supply chain, etc.) and time.

The three types of infrastructure differ for the TRL of their technologies, their main scope, the openness, their funding and business model, as well as for the type of involvement of public authorities.

\subsubsection{Lab-Scale Pilot Plants}

\subsubsection{Concept}

A Lab-scale Pilot Plant is an innovation infrastructure aimed at supporting research and innovation activities to progress in the TRL scale, making technologies more mature and closer to industrial application (from TRL 4-6 to 5-7). Lab-scale Pilot Plants are focused on the design and finalization of integrated technologies for the solution of specific industrial problems [14], by exploiting solutions that are typically the result of research projects. Therefore, these pilot plants are generally set-up (and owned) by research organisations and universities that define also their strategy and operations rules [16]. Innovative research results are transferred into the pilot plants and the main effort in the setup phase is technology integration under a system engineering perspective. Usually, in fact, research projects generate results in single 
technology domains, but a systemic perspective to solve specific industrial challenges is missing. Technological equipment of Lab-scale Pilot Plants consists of integrated production systems or lines that can be used in certain industrial domains, but are not customized for specific industrial applications yet. Thus, pilot technologies present a certain degree of flexibility in order to be adapted to different configuration scenarios. The goal of these pilot plants is exactly to define and demonstrate industrial and technological configurations that can represent innovative solutions for the sectors in which they are applied and that can be scaled-up in other pilot plants at industrial level.

Besides the development of new technology setups for specific industrial scenarios, which is a typical innovation activity, Lab-scale Pilot Plants can also perform some research activities that are necessary to integrate the solutions (especially when their nature is highly multi-disciplinary) or to complete the configuration and testing phase. This justifies the central role that research organisations have in this type of innovation infrastructure, in accordance with the main focus of generating scientific and engineering progress. Moreover, a Lab-scale pilot plant has to be in continuous evolution as it tries to integrate and finalize research results as soon as they become available from research projects. To this aim, Lab-scale pilot plants are frequently used as demonstrators in research and innovation projects.

Even though the main goal of Lab-scale Pilot Plants is to lower technology risk and they are generally owned and managed by a single research organization, such facilities constitute an aggregation point for various innovation stakeholders with an important network effect [18]. Besides research organisations, the stakeholders are mainly technology suppliers, that have to cooperate to integrate technologies in manufacturing systems, and manufacturing end-users, that will be the final adopters of technologies. The degree of openness of such facilities will be intermediate: all key-actors at different supply chain and technology levels should be represented, but their number should not be too high in order not to generate competition, conflict of interest and not to reduce the efficiency of cooperation, as also stated by [14]. Usually, stakeholders are highly reputed research and industrial partners in their competence area, that already cooperate in research and innovation activities.

Lab-scale Pilot Plants can be funded and operated exploiting a mix of instruments. Public research and innovation funding (at European, National and Regional levels) supports the development of innovative technology solutions that can be included in the pilot plant. Dedicated funding programs and Regional/National direct funding to research organisations and universities for the setup of infrastructure can support the creation of the pilot plants through the setup of a facility where multiple technologies are integrated. In-kind contribution can be provided by stakeholders, who are interested in the infrastructure because it is a vehicle for the setup of new solutions that later can be sold in the market or can be directly up-taken before competitors. Revenues can be in the form of research and innovation contracts by customers interested in identifying and testing suitable solutions to solve their industrial challenges as well as in the form of incomes from the first sales of such solutions by providers. 


\subsubsection{De- and Remanufacturing Pilot Plant at CNR-STIIMA}

A relevant example of Lab-scale Pilot Plant is the "Mechatronics De- and Remanufacturing" pilot plant installed at CNR-STIIMA (ex CNR-ITIA). The pilot plant, in its original configuration, was initially funded by Regione Lombardia with a grant of 1.5 million euro. After several upgrades supported by projects and industrial grants, the pilot plant currently includes innovative technologies and prototypes doubling its initial investment.

The pilot plant goal is to integrate and validate at TRL 5-7 a set of multidisciplinary methodologies, tools and technologies for the smart de- and remanufacturing systems of the future, with specific focus on mechatronic products.

The pilot plant was designed and built according to a precise strategy of CNRSTIIMA (ex CNR-ITIA) that, based on the evidence that End-of-Life (EoL) of mechatronics is addressed in a very fragmented and inefficient way in Europe, decided to invest in the setup of a unique research and innovation facility in terms of process integration and multi-disciplinarity of technological enablers. Single technologies, in fact, are currently available separately as the result of research and innovation projects, but until they were not integrated in a plant that can replicate real industrial processes for the achievement of manufacturing objectives.

The pilot plant includes technologies to support products disassembly, remanufacturing and recycling of materials (addressing mechanical pre-treatments), implementing the most valuable EoL strategy according to the parts to be treated. Innovation is pursued at three levels, as represented in Fig. 21.2: at the level of single process/technologies, of the integrated process chain and of business model.

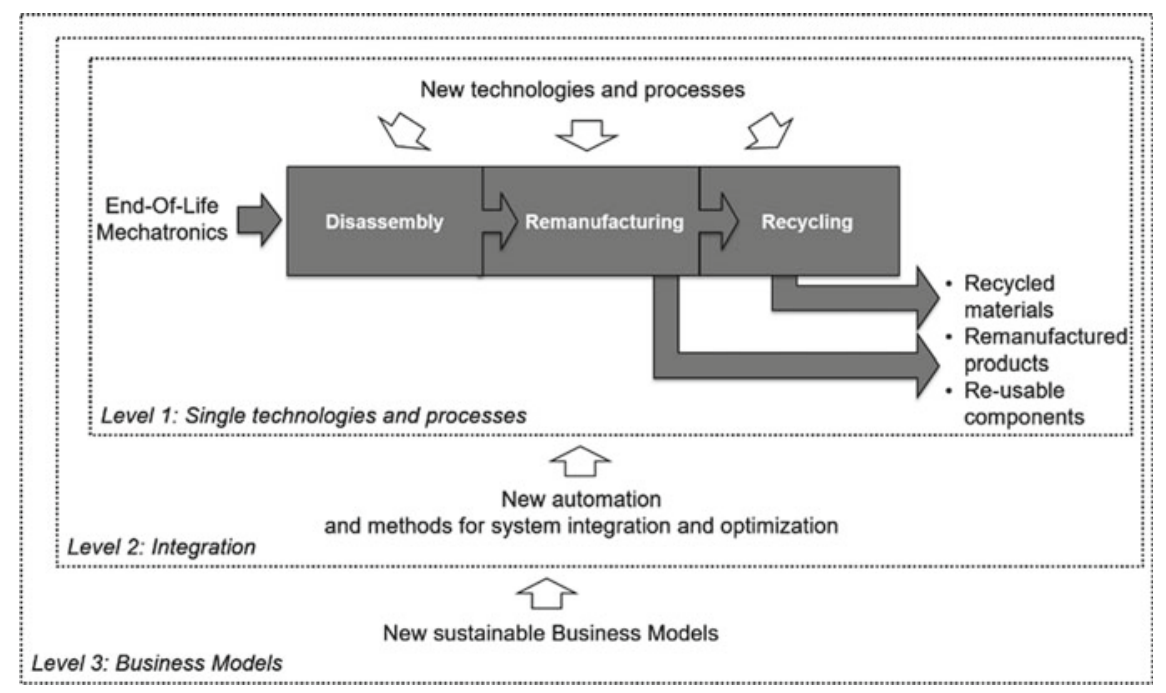

Fig. 21.2 Concept of the lab-scale pilot plant of CNR-STIIMA (ex CNR-ITIA) [19] 
The plant consists of three connected cells. The first cell is dedicated to hybrid disassembly of mechatronic components exploiting the human-robot interaction paradigm. The second cell is dedicated to testing and remanufacturing of printed circuit boards (PCBs) and it exploits highly flexible solutions to adapt to the extreme variability of products. The third cell is dedicated to mechanical pre-treatment with low environmental impact (i.e. shredding and materials separation processes) for the recovery of high-value and critical raw materials from PCBs.

A virtual model (digital twin) connected to the real plant was realised for the implementation of the concept of the Digital de-manufacturing factory.

The pilot plant is fully operational and has been employed mainly for research and innovation objectives within several research and innovation projects, for which it is a differential asset. In addition, the plant supports the offering of technology services to companies willing to test the potential of new integrated technological solutions for circular economy, mainly in the automotive, white goods, and telecommunication sectors. These activities allowed building a community of academics, manufacturers, recyclers, remanufacturers and technology providers that constitutes a pool of qualified service offering parties and potential partners for new research and innovation projects. This community is continuously generating new knowledge around the demonstrated technologies and contributes to the consolidation of supply chain relationships that will be necessary when the demonstrated multi-disciplinary solutions will be sold in the market.

Finally, the pilot plant is used also for training and education according to the learning factory paradigm [20-23].

\subsubsection{Industrial-Scale Pilot Plants}

\subsubsection{Concept}

An Industrial-scale Pilot Plant is an innovation infrastructure aimed at supporting industry in the first uptake of innovative technologies and solutions that have been previously demonstrated in Lab-scale Pilot Plants. Compared to the latter, Industrialscale Pilot Plants are equipped with technologies at higher TRL level (7-8) which resulted to be successful in precedent innovation phases. The level of flexibility of such technologies is consequently lower, and the pilot plant offers a demonstration facility in real industrial environment to quickly and effectively test the benefits of novel solutions with a setup tailored to specific business applications. Thus, the focus of activity is more on demonstration than on design, which is limited to the final customisation of the solution for the specific users' applications. Limited industrial research activities are carried out.

Demonstration activities are meant to reduce uptake risks. By testing the new technologies on their specific products and processes, companies can better measure expected benefits, thus being able to elaborate robust business plans and to define financial needs. They are also able to anticipate organisational issues linked to new 
technologies uptake (e.g. production re-organisation and the need of new skills and competences of operators) that the Industrial-scale Pilot Plants might contribute to address through specific industrial-oriented education programs. Finally, technical services received by these pilot plants support industry in the definition of requirements for the technical integration of new technologies in production plants and in the minimization of the inefficiencies during the ramp-up phase.

The main goal of Industrial-scale Pilot Plants is to offer a wide set of technology and business services supporting the uptake. Consequently, these plants are more open that Lab-scale Pilot Plants. Usually, they are not owned by a unique actor, but they present a multi-ownership structure [16]. Public Authorities might also participate or directly influence the governance of such infrastructure, since they are supposed to generate impacts for entire industrial sectors and they need to have a high level of openness to companies, especially to SMEs. This public-private nature of the infrastructure makes the business model challenging, thus becoming a research topic for future research per se.

The networking dimension associated with these pilot plants is very significant, because, besides the goal of supporting technology demonstration and uptake planning, they are supposed to be a meeting point for companies to build new supply chain partnerships that are needed in future operations of novel technologies.

Funding of this type of innovation infrastructure is challenging because required investments are high and a public-private multi-ownership structure may be involved. Public funding plays a major role in triggering the setup of such innovation infrastructures, since the direct benefit for single organisations and private investors is less clear than Lab-scale Pilot Plants [24]. Revenues for the infrastructure derive from direct service contracts with industrial customers, as well as from possible public incentives schemes (such as vouchers) to stimulate the demand of services by industrial companies.

\subsubsection{Vanguard De- and Remanufacturing Pilot Network for Circular Economy}

The "Vanguard Initiative-New Growth Through Smart Specialisation" is a political initiative of more than 30 European Regions aimed at promoting inter-regional cooperation based on smart specialization. ${ }^{37}$ The goal of Vanguard is to boost industrial innovation exploiting synergies and complementarities of European Regions. With this goal, regions organize themselves in pan-European partnerships of companies, Research and Technology Organisations (RTOs), Universities and other manufacturing stakeholders that propose and manage strategic projects for the establishment of networks of pilot plants supporting the industrial uptake of innovative technologies and the creation of new European value chains. The network of pilot plants is meant to be a public-private service centre open to companies of all Europe, especially SMEs.

\footnotetext{
${ }^{37} \mathrm{https} / / / \mathrm{www} . \mathrm{s} 3$ vanguardinitiative.eu/.
} 


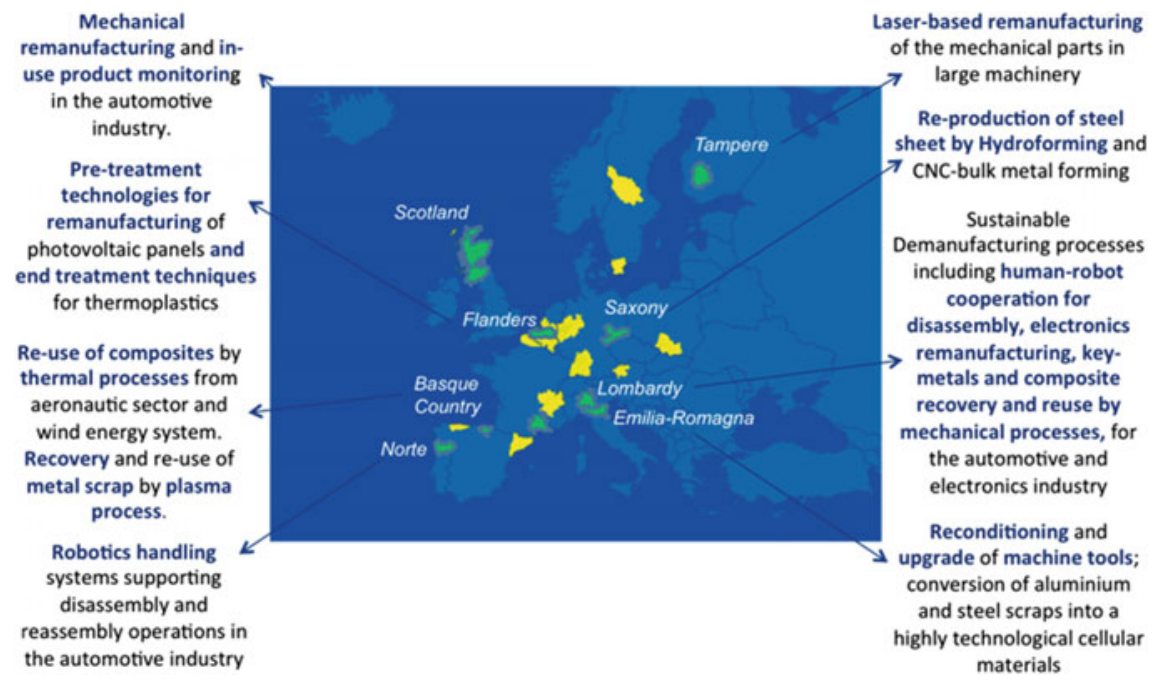

Fig. 21.3 Cross-regional architecture of the De- and Remanufacturing for Circular Economy Pilot Network

Within the Vanguard "Efficient and Sustainable Manufacturing (ESM)" pilot project, the "De- and Remanufacturing for Circular Economy Pilot Plant" was conceived and designed [25]. The cross-regional architecture of the "De- and Remanufacturing" pilot plant currently includes eight Regional Nodes, each of them specialized in a specific testing and demonstration domain (Fig. 21.3).

Each node will be a potential point of access for manufacturing end-users in the same or in other regions, depending on the specific capabilities and target sectors. According to regional specialisation, pilot nodes will include a set of advanced technologies to support companies' uptake in specific domains, e.g. the remanufacturing of electronics products, recycling of composites, re-use and recycling of batteries.

The main concept of the De- and Remanufacturing pilot network is represented in Fig. 21.4. For each industrial problem, the most suitable combination of technologies to retrieve the highest residual value from the post-use product will be tested and validated. The output of this process will be a set of demonstrated integrated technological solutions and circular economy business models to support the implementation of the specific business cases at industrial level.

Currently, the definition of the pilot concept is supported by more than 80 private companies (both SMEs and large companies) at European level with a cumulative turnover of 27 billion euro and with some 150,000 employees, and 68 universities and RTOs distributed among the involved regions. These actors also declared their intention to co-fund the development of the pilot network.

It was estimated that this pilot network can lead to about 35 new industrial installations in five years after its setup, bringing a cumulative revenue for the involved companies of about 215 million euro. 


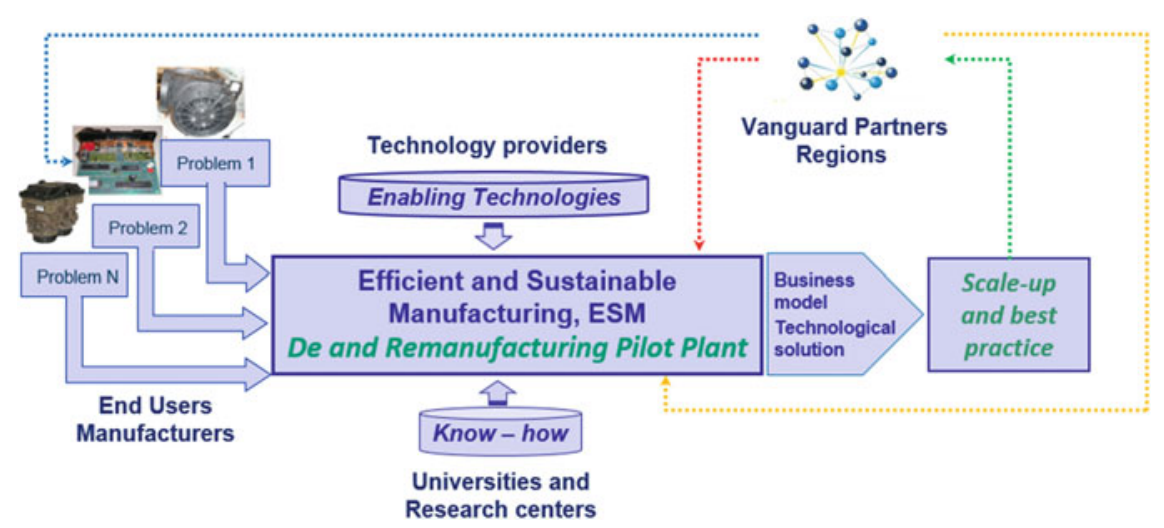

Fig. 21.4 Concept of the De- and Remanufacturing for Circular Economy Pilot Network

The implementation cost of the pilot network is estimated to be 50 million euro. Currently, the Vanguard community and the stakeholders of the pilot plant projects are discussing with European, National and Regional institutions, as well as with banks and other private funding organisations, to define the most appropriate publicprivate funding mix to establish the infrastructure.

The European Commission has recently selected this partnership to offer support through experts' consulting with the aim of removing the existing implementation bottlenecks in the frame of the S3 Platform on Industrial Modernisation.

\subsubsection{Lighthouse Plants}

\subsubsection{Concept}

A Lighthouse Plant (LHP) is an infrastructure that aims at creating a reference production plant, owned by a company and operating in a stable industrial environment, based on key enabling technologies whose benefit was previously demonstrated (e.g. in Lab-scale or Industrial-scale pilot plants). The aim of the LHP is twofold: on the one hand, to demonstrate on a long-term basis novel technologies in operation, thus supporting the continuous uptake by industry; on the other hand, to trigger the development of industrial research and innovation activities to continuously improve manufacturing solutions according to the progress of technology.

LHPs are conceived as evolving systems and are realized ex-novo or based on an existing plant deeply revisited, where collaborative research and innovation, partially funded by public institutions, is carried out by the owner of the plant together with universities, research centres, and technology providers. The results of research and innovation activities are meant to be readily integrated into the plant. The main difference with respect to the other types of pilot plant presented in Sects. 21.3.1 and 
21.3.2 is that LHPs are real plants operated by companies in industrial environments, therefore they prove the sustainability of embedded technologies (TRL 9). A LHP contributes to the generation of new knowledge for the industrial operation of novel technologies. LHPs overcome the purely technology push approach while proposing the use of technologies to solve specific problems, thus creating a link between technologies and a strategy pulled by challenges.

Once realized, a LHP becomes a catalyst for further industrial research and innovation activities, playing the role of test house in subsequent initiatives at regional, national and international level to guarantee that the plant continues supporting over time the uptake of new technologies that are there applied as early user.

Being owned by an industrial company, a LHP will be mainly funded by the company itself, but public authorities can stimulate and co-fund the setup and following research and innovation activities. While guaranteeing intellectual property rights (IPR) and confidentiality of key portions of the plant, the goal is to open as much as possible the LHP to other companies and in general to the industrial system. Educational and training activities must be designed to show how to follow the innovation path, thus increasing the overall culture of the manufacturing network. Various stakeholders can benefit from a LHP:

- Manufacturers can set-up innovative plants that are constantly evolving coherently, while receiving a particular and continuous attention on their industrial issues from technology suppliers, universities and research organisations. The manufacturers will have visibility according to the strategic scope of the plant, which is part of a large LHP network.

- Technology providers have the opportunity to develop new solutions that can be tested in real production plants and be highly visible to potential buyers. This is particularly strategic for SMEs and startup companies.

- SMEs have access to concrete examples of application of new technologies that can inspire several other smaller scale implementations.

- Universities and Research Organisations have the opportunity to be involved in research and innovation projects with production plants as a way to enhance the results of their research and to receive new founding for subsequent activities.

- The supply chain around the plant is positively influenced by the innovation that often requires commitment from different members of the supply chain upstream and downstream.

- Local and national governments have the opportunity to assess concrete results of the implemented innovation actions and to showcase best practices to national and international actors. Based on the results, the local or national governments can also identify strategic initiatives to be funded for basic or applied research in the manufacturing domain. 


\subsubsection{LHP in Italy}

The LHPs concept as presented in the previous section has been defined by Italian Cluster Intelligent Factories (CFI) ${ }^{38}$ to further boost the National Plan Enterprise $4.0^{39}$ designed by the Ministry of Economic Development in Italy (MISE) in 2017. This plan included incentives for super- and hyper-depreciation as a way to support the implementation of advanced technologies in Italian manufacturing companies.

CFI coordinates the LHP initiative in accordance with the strategic action lines identified in its research and innovation roadmap [26]. A formal procedure has been established for the submission of LHP proposals. Each company interested in the LHP initiative can submit a proposal of research and innovation project linked to a new plant (or a deeply renovated one) to the CFI Technical Scientific Committee that will later express its opinion and possibly admit it to the LHP candidate list. CFI supports the preparation of the LHP proposal till the submission to MISE. If the proposal is approved by MISE, the new LHP will receive funding. After the approval, each LHP proposer is invited to set up a scientific-strategic management board for the project; an expert appointed by CFI Coordination and Management Body is invited to participate at least twice a year in the board meetings to discuss:

- the advancement of the project with respect to the workplan;

- consistency and synergy of the project activities with the CFI activities;

- coordination and planning of joint initiatives with CFI.

Furthermore, each LHP project will participate in the Lighthouse Plant $\mathrm{Club}^{40}$ managed by CFI to support:

- promotion of the direct interaction with Ministries;

- visibility of the LHP at national and international level;

- access to a set of competences available among CFI members;

- participation in the initiatives promoted by CFI;

- participation in the training and education activities promoted by CFI;

- identification of follow-up research and innovation initiatives.

Currently, four LHP proposals have already been approved by MISE (see Fig. 21.5), each one with a total value for research and innovation activities ranging from 10 to 19 million euro (in addition to the value of the new plant):

- Ansaldo Energia. ${ }^{41}$ Smart Factory based on the application of Digital Technologies.

\footnotetext{
${ }^{38}$ www.fabbricaintelligente.it.

${ }^{39} \mathrm{http}: / /$ www.sviluppoeconomico.gov.it/index.php/it/industria40.

${ }^{40} \mathrm{http}: / / \mathrm{www}$.fabbricaintelligente.it/english/light-house-club/.

${ }^{41}$ www.ansaldoenergia.com.
} 


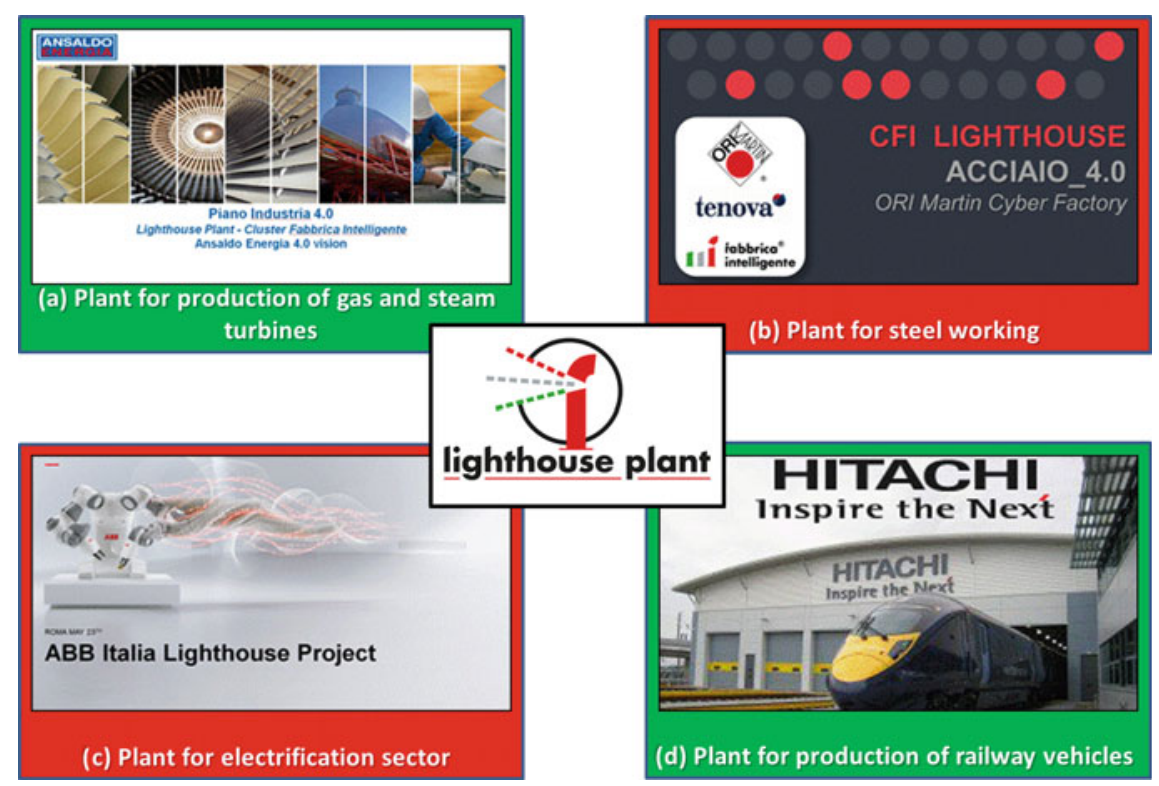

Fig. 21.5 Lighthouse plants approved by MISE: a Ansaldo Energia, b ORI Martin and Tenova, c ABB Italy, d Hitachi Rail Italy. Courtesy of Italian Cluster Intelligent Factories (CFI)

- ORI Martin ${ }^{42}$ and Tenova. ${ }^{43}$ Cyber Physical Factory for steel production from scraps.

- ABB Italy. ${ }^{44}$ Multi-plant factory for the production of the complete Circuit breakers portfolio.

- Hitachi Rail Italy. ${ }^{45}$ New Products Platforms produced in Digital Factories.

MISE Ministry and the local Regions will contribute to the public funding of these research and innovation projects connected to the plant for 36 months by signing a strategic innovation agreement for each Lighthouse Plant.

The LHPs will enable the CFI community, and in particular SMEs, to have a special access to the technologies of Industry 4.0 in real applications.

Acknowledgements This work has been partially funded by the Italian Ministry of Education, Universities and Research (MIUR) under the Flagship Project "Factories of the Future-Italy" (Progetto Bandiera "La Fabbrica del Futuro") [4].

The authors would like to thank Marcello Colledani, Rosanna Fornasiero, and Marcello Urgo for their valuable contributions to this chapter.

\footnotetext{
42 www.orimartin.com.

${ }^{43}$ www.tenova.com.

${ }^{44}$ https://new.abb.com.

${ }^{45}$ http://italy.hitachirail.com/en.
} 


\section{References}

1. Mazzucato M (2018) Mission-oriented research \& innovation in the European Union-a problem-solving approach to fuel innovation-led growth. Publications Office of the European Union. ISBN 978-92-79-79832-0. https://doi.org/10.2777/360325

2. European Commission (2018) Re-finding industry-defining innovation. Publications Office of the European Union. ISBN 978-92-79-85271-8. https://doi.org/10.2777/927953

3. Tolio T, Copani G, Terkaj W (2019) Key research priorities for factories of the future-part I: missions. In: Tolio T, Copani G, Terkaj W (eds) Factories of the future. Springer

4. Terkaj W, Tolio T (2019) The Italian flagship project: factories of the future. In: Tolio T, Copani G, Terkaj W (eds) Factories of the future. Springer

5. Jovane F, Yoshikawa H, Alting L, Boër CR, Westkamper E, Williams D, Tseng M, Seliger G, Paci AM (2008) The incoming global technological and industrial revolution towards competitive sustainable manufacturing. CIRP Ann 57(2):641-659. https://doi.org/10.1016/J.CIRP. 2008.09.010

6. Stokes DE (1997) Pasteur's quadrant—basic science and technological innovation. Brookings Institution Press

7. European Commission (2012) A European strategy for key enabling technologies—a bridge to growth and jobs. $\operatorname{COM}(2012) 341$ final

8. European Commission (2016) An analysis of drivers, barriers and readiness factors of EU companies for adopting advanced manufacturing products and technologies. Accessed at https://ec.europa.eu/growth/content/analysis-drivers-barriers-and-readinessfactors-eu-companies-adopting-advanced-1_en. Accessed 01 Aug 2018

9. European Commission (2015) Promoting the access of SMEs to KETs technology infrastructures. Publications Office of the European Union. ISBN 978-92-79-36385-6. https://doi.org/ $10.2769 / 92236$

10. Schot J, Geels FW (2008) Strategic niche management and sustainable innovation journeys: theory findings, research agenda, and policy. Technol Anal Strateg Manag 20(5):537-554

11. Hekkert M, Suurs R, Negro S, Kuhlmann S, Smits R (2007) Functions of innovation systems: a new approach for analysing technological change. Technol Forecast Soc Change 74(4):413-432

12. Bergek A, Jacobsson S, Carlsson B, Lindmark S, Rickne A (2008) Analyzing the functional dynamics of technological innovation systems: a scheme of analysis. Res Policy 37(3):407-429

13. Smith A, Raven R (2012) What is protective space? Reconsidering niches in transitions to sustainability. Res Policy 41(6):1025-1036

14. Ballon P, Pierson J, Delaere S (2005) Test and experimentation platforms for broadband innovation: examining European practice. http://dx.doi.org/10.2139/ssrn.1331557

15. Frishammar J, Söderholm P, Bäckström K, Hellsmark H, Ylinenpää H (2014) The role of pilot and demonstration plants in technological development: synthesis and directions for future research. Technol Anal Strateg Manag 27(1):1-18

16. Hellsmark H, Frishammar J, Söderholm P, Ylinenpää H (2016) The role of pilot and demonstration plants in technology development and innovation policy. Res Policy 45(9):1743-1761

17. Camarinha-Matos LM, Fornasiero R, Afsarmanesh H (2017) Collaborative networks as a core enabler of Industry 4.0. In: Camarinha-Matos L, Afsarmanesh H, Fornasiero R (eds) Collaboration in a data-rich world. PRO-VE 2017. IFIP advances in information and communication technology, vol 506. Springer, Cham

18. Tichkiewitch S, Shpitalni M, Krause F-L (2006) Virtual research lab: a new way to do research. CIRP Ann 55(2):769-792. https://doi.org/10.1016/J.CIRP.2006.10.007

19. Copani G, Brusaferri A, Colledani M, Pedrocchi N, Sacco M, Tolio T (2012) Integrated Demanufacturing systems as new approach to End-of-Life management of mechatronic devices. In: Proceedings of the 10th global conference on sustainable manufacturing, Istanbul, 31 Oct-2 Nov 2012

20. Mavrikios D, Papakostas N, Mourtzis D, Chryssolouris G (2013) On industrial learning and training for the factories of the future: a conceptual, cognitive and technology framework. J Intell Manuf 24(3):473-485 
21. Chryssolouris G, Mavrikios D, Rentzos L (2016) The teaching factory: a manufacturing education paradigm. Procedia CIRP 57:44-48

22. Abele E, Chryssolouris G, Sihn W, Metternich J, ElMaraghy H, Seliger G, Sivard G, ElMaraghy W, Hummel V, Tisch M, Seifermann S (2017) Learning factories for future oriented research and education in manufacturing. CIRP Ann 66(2):803-826. https://doi.org/10.1016/J.CIRP. 2017.05.005

23. Caldarola E, Modoni G, Sacco M (2018) Manulearning: a knowledge-based system to enable the continuous training of workers in the manufacturing field. In: Proceedings of 12th International conference on e-Learning

24. Mazzucato M (2014) The entrepreneurial state-debunking public vs private sector myths. Anthem Press, New York, USA

25. Efficient and Sustainable Manufacturing (ESM). https://www.s3vanguardinitiative.eu/ cooperations/efficient-and-sustainable-manufacturing-esm. Accessed 31 July 2018

26. Associazione Cluster Fabbrica Intelligente (2015) Roadmap per la ricerca e l'innovazione—research and innovation roadmap. http://www.fabbricaintelligente.it/english/ roadmap/

Open Access This book is licensed under the terms of the Creative Commons Attribution 4.0 International License (http://creativecommons.org/licenses/by/4.0/), which permits use, sharing, adaptation, distribution and reproduction in any medium or format, as long as you give appropriate credit to the original author(s) and the source, provide a link to the Creative Commons licence and indicate if changes were made.

The images or other third party material in this book are included in the book's Creative Commons licence, unless indicated otherwise in a credit line to the material. If material is not included in the book's Creative Commons licence and your intended use is not permitted by statutory regulation or exceeds the permitted use, you will need to obtain permission directly from the copyright holder. 